\title{
Human Health Caring as General Education for Engineers: Introduction to a New Theory with Practice of Nursing
} Naoko Takayama ${ }^{1 *}$ and Hiromi Ariyoshi ${ }^{2}$

${ }^{1}$ Department of Education, Asahi University, Japan

${ }^{2}$ Department of Medicine, Saga University, Japan

\begin{abstract}
Nursing has been given to nurse students as a professional education. But in today's aging society, not only nurses but also general public need to have the basic knowledge and skills of nursing. People with basic knowledge and technique of nursing will be willing to help people with disability.

Then Takayamahas come to realize that the knowledge and skills of nursing will help engineers develop aiding instruments for physically and mentally challenged people. This made the author start a new subject of Human Health Caring for Engineers in the regular curriculum at a college of technology, which is the first regular course not only in Japan but in the world. For the last thirteen years 1,112 students finished the course 'Human Health Caring'. The introduction and evaluation of this nursing education for engineers are reported in this paper.
\end{abstract}

Keywords: Nursing education; Engineering; Subject in regular curriculum; Nursing education; Important roles in hospitals; Social changes

\section{Introduction}

Since Meiji Era nursing education in Japan has been performed as a vocational education for producing professional nurses, who have been doing their important roles in hospitals and clinics. But with social changes like aging society in Japan, the work of nurses has not been limited in medical facilities but has been extended to social communities. The authors have come to realize that under the present day social changes, it is necessary to give nursing education not only to nurses and nurses-will-be but to the general public. The society needs health promotion, industry nursing, help for recovery from diseases and the skills to take care of the disabled and the aged at home. It is obvious that machines and instruments are one of the effective ways to solve these problems. In order to make engineers to be interested in the

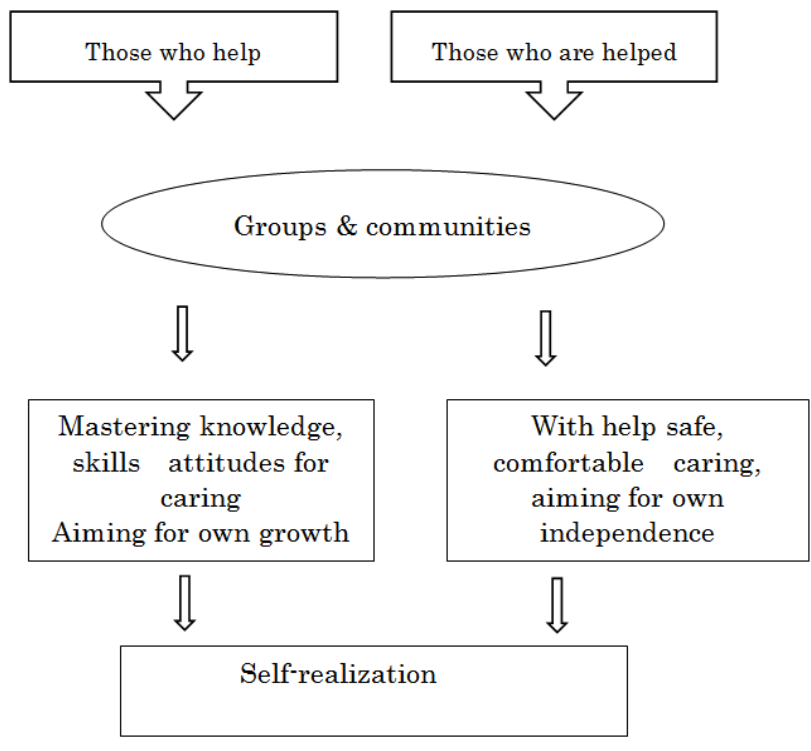

Figure 1: Framework of human health caring. solution of these social problems, we started 'Human Health Caring for Engineers' in the regular curriculum at a national college of technology in 1999. The practice of nursing education for engineers is reported [13].

\section{The aim and the start of 'human health caring'}

The aim of teaching nursing in the regular curriculum is humanity education for engineers. In 1997 the Reformed Gender Equal Employment Opportunity Law was promulgated and the Gender Equal Society Law was enforced in 1999.With these circumstances, gender equality and empowerment have been encouraged at home and in the society, including work places. Changes, though small, have been seen in the male dominant society. This is one of the factors that enabled us to open a nursing course in the college of technology. In Japan, nursing education is categorized into seven fields: Introduction to Nursing, Adult Nursing, Gerontological Nursing, Home Care Nursing, Maternal Nursing, Child Nursing and Mental Nursing [4].

The course was named Human Health Caring and it was a full-year two-credit elective course, the introduction to nursing and nursing art in fundamental nursing being emphasized with gerontological nursing.

\section{Outline of Human Health Caring}

\section{Definition of human health caring}

The Human Health Caring is an activity to help people to maintain and promote health, understanding them as comprehensive beings, that is, as physical, social and mental beings. It is a pragmatic course of study that through the activities not only to help others at every level of health

*Corresponding author: Naoko Takayama, Department of Education, Asahi University, Japan, Tel: 81-58-329-1842; E-mail: takayama@y-nm.ac.jp

Received October 01, 2013; Accepted November 21, 2013; Published December 04, 2013

Citation: Takayama N, Ariyoshi H (2013) Human Health Caring as General Education for Engineers: Introduction to a New Theory with Practice of Nursing. J Biosafety Health Educ 1: 112. doi:10.4172/2332-0893.1000112

Copyright: (c) 2013 Takayama N, et al. This is an open-access article distributed under the terms of the Creative Commons Attribution License, which permits unrestricted use, distribution, and reproduction in any medium, provided the original author and source are credited. 
Citation: Takayama N, Ariyoshi H (2013) Human Health Caring as General Education for Engineers: Introduction to a New Theory with Practice of Nursing. J Biosafety Health Educ 1: 112. doi:10.4172/2332-0893.1000112

Page 2 of 3

and on the process of self-realization but also to aim at the own selfrealization of helping people [2].

\section{Components and framework of human health caring}

Three components are set in the course. The first is humanity which means every phase of life, including study and practical training of gerontology and of physical disability. The second is health which does not only mean the state without sickness but to help people to live independent life with their own quality of life. The third is caring

\begin{tabular}{|c|c|c|c|}
\hline & Reaction of learners & study fields & goals \\
\hline A & understanding & Knowledge & cognitive domain \\
\hline B & realizing \&feeling & Attitudes & affective domain \\
\hline C & helping & motor skills & psychomotor domain \\
\hline
\end{tabular}

Table 1: Study fields, goals\& reaction of learners cf. R.S. Bloom (1966).

\begin{tabular}{|l|}
\hline $\begin{array}{l}1^{\text {st }} \text { step } \\
\text { Basic knowledge of Human Health Caring } \\
\text { (Understanding of humanity, health and society) }\end{array}$ \\
\hline $\begin{array}{l}2^{\text {nd }} \text { step } \\
\text { Basic skills of Human Health Caring } \\
\text { (Skills for communication and for supporting life) }\end{array}$ \\
\hline $3^{\text {rd }}$ step \\
\hline $\begin{array}{l}\text { Exercises: Exercises in campus } \\
\text { Practice: Practice at institutions for old age people }\end{array}$ \\
\hline
\end{tabular}

Table 2: Three steps of human health caring

\begin{tabular}{|c|c|}
\hline Order & Contents \\
\hline 1. & $\begin{array}{l}\text { Introduction to Human Health Caring } \\
\text { Definition, framework, caring, humanism, nursing, life and living skills. }\end{array}$ \\
\hline 2. & $\begin{array}{l}\text { Humanity and development task } \\
\text { Human development stages, developmental task, life ethics, study } \\
\text { of humanity for the equal cooperative society with disabled } \\
\text { people. }\end{array}$ \\
\hline 3. & Helping skills \\
\hline $3-1$ & $\begin{array}{l}\text { Skills of helping human activities } 1 \\
\text { Observation with basic knowledge of vital signs } \\
\text { Communication skills, role plays and process record } \\
\text { Basic knowledge of nutrition and practice of meal }\end{array}$ \\
\hline $3-2$ & $\begin{array}{l}\text { Skills of helping human activities } 2 \\
\text { Basic knowledge of excretion } \\
\text { Activities, recreation and body mechanics } \\
\text { Practice of moving patients } \\
\text { Basic knowledge of wheelchairs, practice with the elderly \& with } \\
\text { wheelchairs } \\
\text { Living environment, sleep, rest, skin care \& clothing }\end{array}$ \\
\hline 4. & $\begin{array}{l}\text { Practice at nursing facilities for the aged } \\
\text { Communication with elderly people } \\
\text { Assistance with wheelchairs } \\
\text { Special bathing machines \& infectious diseases }\end{array}$ \\
\hline 5. & Welfare machines \& universal design \\
\hline 6. & $\begin{array}{l}\text { Social welfare service } \\
\text { Social welfare, Normalization } \& \text { barrier free } \\
\text { Nursing care insurance system }\end{array}$ \\
\hline
\end{tabular}

Table 3: Contents of the course study.

\begin{tabular}{|c|c|c|c|}
\hline Year & Nr. of students & Year & Nr. of students \\
\hline 1999 & 30 & 2006 & 69 \\
\hline 2000 & 103 & 2007 & 81 \\
\hline 2001 & 88 & 2008 & 94 \\
\hline 2002 & 106 & 2009 & 86 \\
\hline 2003 & 81 & 2010 & 91 \\
\hline 2004 & 86 & 2011 & 104 \\
\hline 2005 & 93 & total & 1112 \\
\hline
\end{tabular}

Table 4: The number of course students. which means the practical caring skills that enable learners to help the aged and people with disability, establishing good human relationship. Needless to say, both verbal and non-verbal communications are indispensable for good caring [5].

The framework of Human Health Caring is shown by Figure 1. It shows that people who help as well as those who are helped in groups and communities seem to be aiming at their own independence and self-realization.

\section{Characteristics of human health caring and study fields}

Study fields and attainable goals are shown in Table 1. The aim of this course is to give engineers the opportunities to learn to understand human beings through theory, practice and experience. In the rapidly aging society, not only caring mind and technology but the helping devices are indispensable. We built up the curriculum intending to put these necessities together in our society [6]. The Theory of Curriculum of Nursing Education by Olivia and Watson [7] and the Theory of Communication by Wiedenbach [8] were adopted for building the syllabus.

\section{The outline and steps of learning of the course}

The course was named 'Human Health Caring' in which the course attendants were all engineering major (Table 2).

\section{Syllabus and Teaching Methods in 2012}

\section{Credit number and participants}

2 credit full-year course: elective for 4 th year students.

\section{Aims}

One of the most important aims of this course was to make engineer students concerned about the old and the disabled by learning and experiences. And realize the problems of the society.

\section{Goals}

A. Students are supposed to have knowledge and skills [9] to help the old aged and the disabled by learning and experiences.

B. Students study and understand barrier free and universal design by learning normalization.

C. From the engineering point of view, students are expected to find social problems and the solution.

\section{Contents of the course}

In $2013,24.1 \%$ of the population of Japan is old age people [10]. The life expectancy of male is 79.6 and that of female is 86.4 years old. The objects of caring in this course were elderly and/or disabled people. The students studied about the human development and life cycle and learned the basic knowledge and skills of caring, which is indispensable for developing welfare devices (Table 3).

\section{The number of course students}

The majors of these elective course attendants were mechanical engineering, electric and electro engineering, civil engineering and computer science and engineering (Table 4).

\section{Teaching methods and evaluation}

In order to get the students well-motivated, as the technical terms in nursing being unfamiliar to them, we used audiovisual aids, giving the opportunities for practices and experiences (Tables 5 and 6). 
Citation: Takayama N, Ariyoshi H (2013) Human Health Caring as General Education for Engineers: Introduction to a New Theory with Practice of Nursing. J Biosafety Health Educ 1: 112. doi:10.4172/2332-0893.1000112

Page 3 of 3

\begin{tabular}{|l|c|l|}
\hline Methods & Frequency & \multicolumn{1}{|c|}{ Contents } \\
\hline Lecture & 13 & Introduction, human development \\
\hline Workshop & 1 & A good life \\
\hline Exercise & 10 & Personal history \\
\hline & & $\begin{array}{l}\text { Communication analysis by process record } \\
\text { Self-care and room setting }\end{array}$ \\
\hline $\begin{array}{l}\text { Planning daily schedule and events at an elderly } \\
\text { home }\end{array}$ \\
\hline \begin{tabular}{l} 
Role playing \\
\hline Vital sign measuring \\
\hline Meal assistance
\end{tabular} \\
\hline \begin{tabular}{l} 
Practice of moving patients \\
\hline $\begin{array}{l}\text { Practice } \\
\text { (off campus) }\end{array}$
\end{tabular} & 1 & $\begin{array}{l}\text { Experience on wheelchairs \&, experience with the } \\
\text { elderly people }\end{array}$ \\
\hline Practice at a nursing welfare elderly home \\
\hline $\begin{array}{l}\text { Audiovisual } \\
\text { aids }\end{array}$ & 5 & $\begin{array}{l}\text { Assistance of disabled people } \\
\text { Meal assistance }\end{array}$ \\
\hline $\begin{array}{l}\text { Excretion assistance } \\
\text { Changes of position }\end{array}$ \\
\hline
\end{tabular}

Table 5: Teaching methods.

\begin{tabular}{|c|c|}
\hline Evaluator & $\begin{array}{c}\text { Content of Evaluation } \\
\text { Excellent- } 4.6 / 5\end{array}$ \\
Students & $\begin{array}{c}\text { Eye opener about humanity } \\
\text { (Attentive, positive, few failed) }\end{array}$ \\
\hline Facility director & $\begin{array}{c}\text { Greatly expect on engineers' concern about the needs of the } \\
\text { old and the disabled }\end{array}$ \\
\hline Facility nurse & Real practical education needed by society \\
\hline Society & Awarded by the Japan National Higher Education \\
Council(2006)
\end{tabular}

Table 6: The evaluation of the course.

\section{Results of practice at a nursing welfare elderly home}

The institution for student practice was a large nursing welfare elderly home in $\mathrm{G}$ city. Thanks to thoughtfulness of the institution, students were given rich practice, which was the afternoon periods in the second semester, after studying about elderly people, infection of diseases and experiencing elderly life and wheel chairs [11].

\section{Aims of practice}

1. To cultivate attitude to respect elderly people by learning and experiencing with them.

2. To learn about welfare machines and barrier free

3. To learn about welfare social resources and welfare services at welfare facilities.

After the orientation by the head of a welfare institution, students start practice beginning with wheelchairs to various welfare machines and devices. They learn and experience much of hardware and software of the institution. At the end of practice they establish good communication and relationship with elderly people. They experience pleasure of being thanked.

\section{Conclusion}

\section{Significance of human health caring at a college of technology}

There has been a great expectation that engineers are able to contribute not only to the development of welfare machines and devices but to the improvement of houses and buildings of these facilities.

\section{Teaching method}

Engineering students, unfortunately, have not many opportunities to learn about humanity. The practice at nursing institutions for elderly people has become an eye opener with humanity. Learning by experience has been effective

\section{Nursing education}

In today's aging society, non-professional nursing education is indispensable in order to live together, helping one another. Needless to say, a great many people are to be helped with new inventions and innovation by engineers.

\section{Inner changes of students}

After the practice at the nursing welfare facilities, the students have come to show deep understanding with elderly people. They also have realized the important social role of engineering by the experience of being thanked by elderly people in the facility.

\section{References}

1. Erikson EH (2001) Identity and the Life Cycle. Kanazawa Press 113-417.

2. Hatano K (1998) Basic Nursing 1, Introduction to Nursing. Medical Press 2-158.

3. Takayama N (2008) Human health caring as general science of engineering: introduction to a new theory and practice of nursing. Japan Society for Welfare Engineering 10: 2-7.

4. Takayama N (2004) Human Health Caring. Educational Press Center 1-121.

5. Takayama N (2007) Introduction to Caring Skills Educational Press Center 1-66.

6. Takayama N (2000) A Study on Nursing Education to the Students of a College of Technology. Journal of Japanese Society of Nursing 23: 279.

7. Olivia EB, Watson J (1989) Toward a Caring Curriculum: A New Pedagogy for Nursing. Medical Press 1-396.

8. Wiedenbach E (1964) Clinical Nursing-A Helping Art, pp.13-136 Gendai Press.

9. Takayama N (2001) Human Health Caring as General Science with New Theory and Practice of Nursing. Research Report of Anan National College of Technology. 37: 47-55.

10. Takayama N (2002) A Study of Understanding of the Old-Age People by Engineering Students and the Influence Factors. Research Report of Anan National College of Technology. 38: 43-51.

11. Journal of Health and Welfare Statistics (2011) Health, Labor and Statistics Association 58. 